\title{
INTERJEKSI DALAM KOMENTAR TERHADAP CUITAN AKUN TWITTER (a)ASKNONYM: KAJIAN MORFOLOGI
}

\section{INTERJECTION IN THECOMMENTSON@ASKNONYM'S TWEET: A MORPHOLOGICAL STUDY}

\author{
Rima Rismaya, Agus Nero Sofyan
}

Universitas Padjadjaran

Ponsel: 081224717483; Pos-el: rima19002@mail.unpad.ac.id, sofyanagusnero@gmail.com

\begin{abstract}
Abstrak
Interjeksi sebagai bagian dari kata tugas bahasa Indonesia digunakan dalam media sosial, salah satunya Twitter. Namun, interjeksi yang digunakan lebih bervariasi karena pengguna Twitter terkesan bebas menggunakan kata apapun untuk mengekspresikan cuitannya. Penelitian ini bertujuan untuk mendeskripsikan bentuk dan fungsi interjeksi yang terdapat dalam Twitter. Penelitian ini merupakan penelitian deskriptif kualitatif dengan teknik simak dan catat sebagai teknik pengumpulan data. Adapun analisis data dilakukan dengan menggunakan metode agih yaitu teknik bagi unsur langsung (BUL) sebagai teknik dasar dan teknik lesap sebagai teknik lanjutan. Berdasarkan penelitian yang dilakukan, terdapat lima jenis interjeksi yang digunakan dalam komentar terhadap cuitan akun Twitter@asknonym, antara lain: (1) interjeksi kekesalan; (2) interjeksi kekagetan; (3) interjeksi kejijikan; (4) interjeksi keheranan; dan (5) interjeksi ajakan.

Kata-kata kunci: morfologi; interjeksi; cuitan; Twitter

\section{Abstract}

As a part of the word of assignment in Indinesian language, interjection is used in social media, one of which is Twitter. However, the interjections used have more varieties since Twitter users seem free to use any word in making the tweets. This research aims to describe the form and function of interjection in Twitter. This research uses qualitative descriptive method and the data is collected by using observation and note-taking technique. The data analysis is conducted by using distributional method, with Immediate Constituent Analysis (ICA) as basic technique and the elipsis technique as an advanced technique. Result of the research shows that there are five types of interjection used in the comments on the Twitter account@asknonym, namely: (1) annoyance interjection; (2) shock interjection; (3) disgust interjection; (4) amazed interjection; and (5) invitation interjection.
\end{abstract}

Keywords: morphology; interjection; tweet; Twitter 


\section{Pendahuluan}

Bahasa sebagai sarana komunikasi yang digunakan oleh manusia mengalami perkembangan seiring berjalannya waktu. Hal ini juga berlaku untuk bahasa Indonesia. Secara umum, bahasa Indonesia dibagi menjadi bahasa formal dan nonformal. Ragam bahasa nonformal adalah ragam yang paling banyak menghasilkan kosakata baru karena penggunaan bahasa nonformal ini seringkali tidak mengikuti kaidah tata bahasa baku bahasa Indonesia. Dalam ragam nonformal, ketika suatu kata dipahami maknanya secara kolektif oleh suatu kelompok masyarakat, maka kata tersebut bisa aktif digunakan dalam percakapan. Bentuk-bentuk kosakata baru ini seringnya tidak mengindahkan kaidah tata bahasa baku bahasa Indonesia. Namun, hal inilah yang menambah keragaman bahasa Indonesia itu sendiri.

Perkembangan zaman juga ikut memengaruhi terbentuknya ragam bahasa baru sebagai bagian dari bahasa nonformal, yaitu bahasa media sosial. Media sosial adalah sebuah media daring yang penggunanya bisa dengan mudah berpartisipasi, berbagi, maupun menciptakan isi atau konten meliputi blog, jejaring sosial, wiki, forum, dan dunia virtual (Cahyono, 2016: 142). Sebagai salah satu media komunikasi saat ini, media sosial menghadirkan peristiwa komunikasi yang lebih ringkas karena adanya aturan-aturan tertentu pada setiap masing-masing media sosial. Salah satu contoh aturan ini adalah adanya pembatasan karakter pada Twitter. Twitter memberlakukan batasan karakter untuk setiap cuitan atau unggahan, yaitu sebanyak 280 karakter atau huruf. Maka dari itu, bahasa yang digunakan pun harus dipersingkat dan dibuat menjadi ringkas. Hal ini berkemungkinan menyebabkan lahirnya istilah-istilah baru karena masyarakat menjadi lebih kreatif menggunakan bahasa Indonesia dalam media sosial. Susanti (2016:231) berpendapat bahwa tidak tertutup kemungkinan istilah tersebut menjadi bahasa resmi yang menambah perbendaharaan kosakata bahasa Indonesia.

Diksi atau pilihan kata dalam bahasa media sosial memang tidak diatur dalam kaidah diksi. Hal-hal yang diatur dalam kaidah diksi adalah proses pembentukan kata dan pemilihan kata (Hakim, dkk., 2017:109). Kebebasan pemilihan diksi inilah yang sering kali menimbulkan kesalahpahaman.

Penelitian mengenai ragam bahasa dalam media sosial pernah dilakukan oleh 
Mansyur mengenai penggunaan bahasa gaul dan alay dalam media sosial yang mengakibatkan terancamnya eksistensi bahasa Indonesia (Mansyur, 2016). Kemudian, penelitian mengenai analisis bahasa media sosial juga pernah dilakukan oleh Swandy, yaitu menganalisis penggunaan bahasa gaul dalam Facebook (Swandy, 2017).

Baik bahasa formal maupun bahasa dalam media sosial, keduanya tidak luput dari proses pembentukan kosakata yang akhirnya membentuk bahasa itu sendiri. Morfologi sebagai bagian dari ilmu tata bahasa mengkaji mengenai pembentukan dan penggunaan beragam kategori kata.

Interjeksi sebagai salah satu bagian dari kategori kata bahasa Indonesia juga banyak digunakan dalam bahasa media sosial. Hal ini disebabkan karena interjeksi merupakan salah satu kata tugas yang digunakan untuk menyatakan suasana hati penutur. Masing-masing interjeksi memiliki makna yang berbeda-beda, bergantung pada situasi dan kondisi tuturan ketika interjeksi itu digunakan (Fadhilah dkk., 2019:43).

Penelitian mengenai interjeksi pernah dilakukan oleh Azwar \& Agustina dengan topik utama yaitu penggunaan interjeksi dalam talkshow "Pagi-Pagi Pasti Happy" di Trans TV (Azwar \& Agustina, 2019).
Selain itu, Milka (2012) juga meneliti interjeksi, yaitu penggunaan interjeksi ya! dan nah! dalam novel "Pemburu Rembulan" karya Arul Chandrana.

Namun, belum ada penelitian khusus mengenai penggunaan interjeksi dalam media sosial, khususnya Twitter. Penelitian ini menarik untuk dilakukan karena ragam bahasa media sosial cenderung sangat produktif yang menghasilkan kosakata baru yang belum pernah ada, misalnya hadirnya interjeksi anjir, anjay, anjrit, anjrot, anjis, anjeng, dan anzeng yang disinyalir merupakan variasi interjeksi anjing, karena kata anjing dianggap terlalu kasar.

Penelitian ini dilakukan untuk menganalisis penggunaan interjeksi dalam media sosial, yaitu interjeksi dalam akun Twitter@asknonym. Secara khusus, penelitian ini bertujuan untuk (1) mendeskripsikan bentuk interjeksi dalam komentar terhadap cuitan akun twitter @asknonym; dan (2) mendeskripsikan fungsi interjeksi dalam komentar terhadap cuitan akun twitter@asknonym.

\section{Landasan Teori}

Morfologi merupakan bagian dari struktur bahasa yang mencakup kata dan bagian-bagian kata, yakni morfem (Kridalaksana, 2009:159). Kategori kata 
adalah sistem klasifikasi kata yang meliputi verba, adjektiva, adverbia, nomina, pronomina, numeralia, dan kata tugas (Alwi, dkk. 2010:91--313). Kata tugas terdiri dari beberapa bagian, salah satunya adalah interjeksi.

Milka (2012:51) memaparkan interjeksi sebagai kata yang berfungsi untuk mengungkapkan perasaan seseorang. Dengan kata lain, interjeksi berfungsi untuk memperjelas suasana kalimat. Djajasudarma (2010:52) juga mengemukakan interjeksi atau kata seru sebagai kata-kata yang berfungsi mengungkapkan perasaan. Widiatmoko \& Waslam (2017:84) menjelaskan bahwa interjeksi berbeda dengan kelas kata lain (verba, adjektiva, adverbia, dan nomina) karena sebagai kata tugas, interjeksi hanya mempunyai makna gramatikal dan tidak mempunyai arti leksikal.

Putrayasa (2017:66) menjelaskan dua bentuk interjeksi, yaitu (a) bentuk dasar, misalnya aduh, aduhai, ah, ahoi, amboi, asyoi, ayo, bah, cis, cih, eh, hai, idih, ih, lho, mari, oh, nah, sip, wah, wahai, yaaa; dan (b) bentuk turunan, biasanya berasal dari kata-kata atau penggalan kalimat Arab, misalnya alhamdulillah, astaga, brengsek, busyet, dubilah, duhilah, insya Allah, syukur, halo, yahud.
Dalam penggunaannya, interjeksi dijabarkan menjadi beberapa jenis. Penjenisan interjeksi ini didasarkan pada perasaan yang diungkapkannya. Berikut ini jenis-jenis interjeksi menurut Alwi, dkk. (2010:309).

a. Interjeksi kejijikan: bah, cis, cih, ih, idih.

b. Interjeksi kekesalan: brensek, sialan, buset, keparat.

c. Interjeksi kekaguman atau kepuasan: aduhai, amboi, asyik.

d. Interjeksi kesyukuran: syukur, alhamdulillah.

e. Interjeksi harapan: insya Allah.

f. Interjeksi keheranan: aduh, aih, ai, lo, duilah, eh, oh, ah.

g. Interjeksi kekagetan: astaga, astagfirullah, masyaallah.

h. Interjeksi ajakan: ayo, mari.

i. Interjeksi panggilan: hai, he, eh, halo.

j. Interjeksi simpulan: nah.

Dalam media sosial, seringkali kosakata bahasa Indonesia yang digunakan adalah kosakata yang telah melalui proses abreviasi. Chaer (2012:191) mendefinisikan abreviasi atau pemendekan sebagai proses penanggalan bagian-bagian leksem atau gabungan leksem sehingga menjadi bentuk baru yang singkat, tetapi maknanya tetap sama dengan makna bentuk utuhnya. Kemudian, Verlin dkk. 
(2018:278) juga menjelaskan abreviasi sebagai proses penanggalan sebagian atau beberapa bagian leksem yang membentuk kata baru tanpa mengubah arti.

Abreviasi dibagi menjadi beberapa jenis (Kemdikbud, 2016), antara lain: (a) singkatan yaitu hasil menyingkat berupa gabungan huruf, misalnya KTP (Kartu Tanda Penduduk); (b) akronim yaitu kependekan yang berupa gabungan suku kata, misalnya rudal (peluru kendali); (c) penggalan yaitu pemendekan yang mengekalkan salah satu bagain dari leksem, misalnya dokter menjadi dok; (d) kontraksi yaitu pemendekan dengan cara menghilangkan satu atau lebih fonem, misalnya tidak menjadi tak; (e) lambang huruf, yaitu bentuk penggunaan huruf awal dalam sebuah kata dan biasanya merupakan bentuk satuan, misalnya kilogram menjadi $\mathrm{kg}$.

Adapun Twitter merupakan media sosial yang memungkinkan penggunanya mengirim cuitan untuk kemudian ditanggapi pengguna lainnya. Secara umum, Twitter berisi cuitan mengenai halhal pribadi berupa cerita atau opini yang dibagikan oleh pengguna kepada orangorang pilihan (Nurhadi, 2017:540). Akun Twitter@asknonym adalah sebuah akun (base) yang memungkinkan pengguna lain mengirim cuitan dengan tanpa menyertakan identitasnya melalui akun ini.

Dalam Twitter, bahasa yang digunakan biasanya merupakan bahasa gaul atau alay dengan ciri khas banyaknya penggunaan akronim, termasuk interjeksi yang berupa akronim. Penggunaan makian bukan lagi hal yang tabu, meskipun seringkali makian tersebut dipelesetkan sehingga menghasilkan bentuk baru. Makian yang juga berfungsi sebagai interjeksi biasanya hadir dalam bentuk penggalan, misalnya kata anjing yang dipenggal menjadi jing dan kata monyet yang dipenggal menjadi nyet. Bentuk penggalan ini sesuai dengan kaidah penggalan dalam akronim bahasa Indonesia oleh Kridalaksana (2010:172), yaitu penggalan melalui pengekalan suku terakhir suatu kata.

\section{Metode Penelitian}

Twitter tidak membatasi seseorang untuk memberikan komentar terhadap cuitan apapun selama akun pemilik cuitan tersebut tidak dikunci. Hal yang sama juga berlaku untuk akun @askonym, yang mana pengguna bebas ikut berkomentar terhadap cuitan anonym pada akun tersebut. Akun ini memiliki lebih dari 356 ribu pengikut. Jika melihat dari berbagai cuitan beserta komentar dalam akun ini, pengikut@asknonym didominasi oleh 
kaum anak muda dengan ciri khas dan catat (Fitriani \& Endriani, 2018:142). penggunaan bahasa slangnya, termasuk Sumber data penelitian ini adalah variasi interjeksi baru yang belum pernah interjeksi yang terdapat dalam komentar dibahas dalam teori interjeksi. pengguna Twitter terhadap cuitan akun Berdasarkan hal tersebut, akun ini dipilih @asknonym pada 19 Mei 2020. Cuitan karena dianggap mampu merefleksikan tersebut berisi tangkapan layar percakapan ciri khas penggunaan interjeksi dalam dua pengguna Twitter lain yaitu media sosial Twitter. Selain itu, pemilihan cuitan yang dijadikan rujukan sumber penelitian ini dipilih karena cuitan tersebut mendapatkan banyak komentar dari pengguna Twitter. Komentar-komentar tersebut menggunakan beragam interjeksi yang lazim digunakan oleh pengguna Twitter dalam cuitan atau komentar mereka pada akun Twitter yang lainnya.

Analisis penggunaan interjeksi dalam komentar terhadap cuitan akun Twitter @asknonym ini termasuk ke dalam jenis penelitian deskriptif kualitatif. Hal ini disebabkan karena penelitian ini bertujuan untuk memberikan gambaran atau deskripsi tentang suatu keadaan secara objektif (Akmaluddin, 2018:7). Dalam penelitian kualitatif, yang menjadi instrumen atau alat penelitian adalah peneliti itu sendiri (Sugiyono, 2017:101). Maka dari itu, peneliti sebagai instrumen segera melakukan analisis data setelah data diperoleh.

Adapun pengumpulan data dalam pertanyaan "Ada ga sii cowo yang gapernah minta pap ke cewe?" dengan jawaban "Gua, soalnya cewe gua burik. Malas liat mukanya". Cuitan pada akun @asknonym ini mendapat 296 retweet, 3749 suka, dan 993 komentar. Di antara komentar-komentar tersebut, terdapat 24 komentar yang menggunakan interjeksi bahasa Indonesia.

Analisis data dalam penelitian ini menggunakan metode agih dengan teknik dasar bagi unsur langsung, yaitu satuan lingual datanya dibagi menjadi beberapa unsur atau bagian (Zaim, 2015:179). Teknik bagi unsur langsung (BUL) digunakan untuk memilah setiap interjeksi yang terdapat dalam sumber data (Junawaroh, 2015:49), misalnya kalimat "yuk kita cari cewenya" dengan pembagian yuk sebagai interjeksi, kita sebagai nomina pengisi fungsi subjek, cari sebagai verba pengisi fungsi predikat, dan ceweknya sebagai nomina pengisi fungsi objek.

penelitian ini menggunakan teknik simak 
Selanjutnya, digunakan teknik lesap sebagai teknik lanjutan (Wahyudi Rahmat, 2017:23). Teknik ini digunakan untuk menentukan fungsi interjeksi dengan cara membandingkan sumber data yang menggunakan interjeksi dengan sumber data yang interjeksinya telah dilesapkan atau dihilangkan, misalnya membandingkan kalimat berinterjeksi " $y u k$ kita cari cewenya" dengan kalimat tanpa interjeksi "kita cari ceweknya". Pada kalimat kedua, penghilangan interjeksi yuk mengakibatkan hilangnya ajakan sehingga kalimat ajakan tersebut berubah menjadi kalimat berita. Adapun untuk uji keabsahan data, penelitian ini dilakukan melalui uji kredibilitas dengan cara menggunakan bahan referensi, meningkatkan ketekunan, dan melakukan analisis kasus negatif (Sugiyono, 2017:185--193).

Hasil analisis data penelitian ini disajikan dalam bentuk deskripsi secara terperinci dengan menggunakan istilah penutur, yaitu orang yang menulis "Gua, soalnya cewe gua burik. Malas liat mukanya", dan petutur yang merujuk pada sumber data, yaitu orang yang menuliskan komentar terhadap cuitan akun Twitter @asknonym.

\section{Pembahasan}

Berdasarkan hasil analisis penggunaan interjeksi dalam komentar terhadap cuitan akun Twitter@asknonym, ditemukan 24 interjeksi dengan rincian fungsi interjeksi sebagai berikut.

\section{a. Interjeksi Kekesalan}

Data:

(1) Emang luu secakep apa sih anjir.

(2) Ya kl burik ngapain lu pacarin nyet.

(3) Muka lu kaya remahan gorengan aja sok cakep jingan.

Interjeksi anjir pada data

merupakan variasi kata anjing yang saat ini sangat umum digunakan oleh kalangan anak muda. Penggunaan kata anjing dalam kalimat masih dianggap sebagai suatu hal yang sangat kasar dan tidak sopan. Maka dari itu, kata anjing yang digunakan sebagai interjeksi berubah menjadi anjir, anjrit, anying, dan anjay. Sama halnya dengan kata anjing yang bisa digunakan sebagai interjeksi, anjir pun dalam data tersebut merupakan bentuk interjeksi untuk mengekspresikan rasa kesal terhadap sesuatu. Penulisan interjeksi anjir juga sangat beragam. Dalam sumber data, ditemukan pula interjeksi anjir yang ditulis menjadi anjirrr, anjr, dan njir. Namun, ada pula yang masih mempertahankan interjeksi anjing tetapi berubah penulisannya menjadi anjg. Baik interjeksi anjir, anjr, njir, dan anjg, 
semuanya bisa digunakan sebagai memaki seseorang yang dianggap berbuat interjeksi yang menyatakan kekesalan.

onar. Namun, dalam data (3), makian

Pada data (2), interjeksi nyet

bajingan dipenggal sehingga merupakan interjeksi bentuk turunan yang menghasilkan dua suku kata terakhir yang mengalami pemenggalan. Bentuk dasar digunakan sebagai makian, yaitu kata interjeksi tersebut adalah monyet yang jingan. Interjeksi jingan termasuk ke kemudian dipenggal menjadi nyet, sesuai dalam interjeksi kekesalan karena dengan kaidah penggalan menurut digunakan dalam kalimat sindiran yang Kridalaksana (2010:172). Kata monyet diakibatkan oleh rasa kesal petutur.

merupakan salah satu ragam makian. b. Interjeksi Kekagetan

Dalam percakapan, monyet dikategorikan sebagai makian yang pada akhirnya termasuk ke dalam interjeksi karena digunakan untuk menyatakan perasaan kesal. Sama seperti kata makian anjing, makian monyet terlihat jarang digunakan secara utuh dalam cuitan maupun komentar pengguna Twitter. Data (2) menunjukkan interjeksi nyet sebagai interjeksi yang menyatakan kekesalan. Interjeksi ini digunakan di akhir kalimat sebagai penekanan terhadap kekesalan yang dirasakan oleh petutur.

Interjeksi jingan pada data (3) juga merupakan interjeksi bentuk turunan yang mengalami pemenggalan. Bentuk dasar interjeksi tersebut adalah bajingan yang kemudian dipenggal menjadi jingan. Kata makian bajingan berasal dari kata bajing, yaitu sejenis hewan pengerat yang sering merusak sesuatu. Maka dari itu, makian bajingan seringkali digunakan untuk

Data:

(4) Terus kalo menurut dia burik kenapa dia pacarin sih astagfirullah.

(5) Wah apakah ak buluk.

(6) Njir pdhl cowoknya lebih dari burik. Interjeksi astagfirullah dalam data (4) merupakan interjeksi yang menyatakan kekagetan sebab digunakan untuk menyertai kalimat yang menyatakan rasa kaget terhadap suatu hal, yang dalam hal ini merupakan kekagetan terhadap sikap kasar petutur yang menghina pacarnya yang dianggap tidak cantik. Dalam data (4), interjeksi astagfirullah termasuk ke dalam interjeksi turunan karena dihasilkan dari penggalan kalimat bahasa Arab yaitu astagfirullahaladzim. Penggunaan interjeksi ini bisa ditempatkan di awal maupun akhir kalimat. Secara umum, interjeksi astagfirullah memang digunakan untuk menyertai perasaan kaget dengan tendensi makna peristiwanya negatif.

Pada data (5), interjeksi wah merupakan interjeksi bentuk dasar untuk 
menyatakan kekagetan. Dalam komentar tersebut, kekagetan yang dialami oleh penutur disebabkan karena ia mempertanyaan kecantikan dirinya sendiri setelah membaca pernyataan dalam cuitan akun@asknonym tersebut.

Data (6) yaitu interjeksi njir merupakan interjeksi bentuk turunan yang telah mengalami proses abreviasi yaitu pemenggalan. Interjeksi njir merupakan variasi penulisan interjeksi anjir yang terdapat dalam data (1). Bentuk dasar interjeksinya adalah anjir, tetapi dipenggal sehingga bentuk njir yang digunakan dalam tuturan. Interjeksi njir dalam data (6) menunjukkan kekagetan petutur terhadap kenyataan fisik penutur cuitan yang dianggapnya lebih jelek dari wanita yang disebutkan oleh penutur cuitan.

\section{c. Interjeksi Kejijikan}

Data:

(7) Idih kayaknya puas bgt bercandain cewenya tentang fisik.

(8) Kyk dia secakep jaehyun aja cuih.

(9) Dih, sok asik dah.

Pada data (7), interjeksi idih merupakan interjeksi bentuk dasar untuk menyatakan kejijikan. Rasa jijik ini tergambar dalam kalimat "Kayaknya puas bgt (banget)". Kata kayaknya menyatakan keadaan yang belum pasti. Namun, data (7) menunjukkan petutur telah merasa cukup yakin bahwa penutur cuitan telah puas membuat candaan mengenai fisik pacarnya, sehingga interjeksi idih digunakan dalam kalimat tersebut. Saat ini, lelucon yang membawa bentuk fisik seseorang sedang dikecam dan ditentang. Maka dari itu, ketika penutur cuitan menjadikan fisik pacarnya sebagai lelucon, petutur menganggapnya sebagai penghinaan. Keadaan ini menjadikan petutur merasa jijik terhadap penutur cuitan tersebut.

Data (8) menunjukkan penggunaan interjeksi bentuk dasar yaitu cuih . Interjeksi cuih merupakan interjeksi yang dihasilkan dari tiruan bunyi ketika seseorang membuang ludah. Dalam kultur masyarakat Indonesia, membuang ludah ketika sedang menanggapi sesuatu diartikan sebagai sikap yang menyatakan rasa jijik. Hal ini juga berlaku pada data (8). Data ini memuat kalimat sindiran yang disertai dengan perasaan jijik dengan cara mengibaratkan penutur cuitan dengan orang lain yang lebih tampan.

Interjeksi dih pada data (9) juga merupakan interjeksi bentuk dasar yang menyatakan kejijikan. Penggunaan interjeksi dih pada data tersebut digunakan sebagai penjelas suasana yang dinyatakan oleh frasa sok asik. Namun, terdapat interjeksi lain dalam data (9) yaitu interjeksi dah. Interjeksi dah dalam data ini juga berposisi sebagai penjelas suasana 
tuturan, tetapi diletakkan di akhir tuturan sebagai sebuah bentuk penekanan. Artinya, petutur benar-benar merasa jijik terhadap sikap penutur dalam cuitannya.

\section{d. Interjeksi Keheranan}

Data:

(10) Susah banget ya ngehargain orang lain heran deh.

(11) Ya napa dipacarin kalau bisanya ngatain elahhh.

(12) Pea bgt $d a h$.

Interjeksi deh pada data (10)

merupakan interjeksi bentuk dasar yang menyatakan perasaan heran terhadap sesuatu. Interjeksi deh bisa digunakan tanpa mencantumkan kata heran sebelumnya. Namun dalam data (10), kata heran juga digunakan oleh petutur dalam tuturannya, sehingga fungsi interjeksi deh menjadi lebih jelas.

Pada data (11), interjeksi elah juga merupakan interjeksi bentuk dasar yang menyatakan keheranan. Interjeksi elah muncul dari kata yaelah, tetapi bentuk elah yang digunakan. Kata yaelah biasanya digunakan dalam percakapan nonformal untuk merendahkan sesuatu, misalnya dalam kalimat yaelah gitu aja gak bisa. Namun, interjeksi elah dalam data (11) tidak digunakan untuk merendahkan penutur cuitan. Interjeksi elah digunakan untuk menunjukkan keheranan petutur terhadap sikap penutur dalam cuitannya. Petutur merasa heran karena penutur cuitan melakukan penghinaan terhadap pacarnya sendiri.

Interjeksi dah pada data (12) termasuk ke dalam interjeksi keheranan karena petutur merasa heran terhadap kapasitas pemikiran penutur cuitan yang dianggapnya kurang. Kata pea merupakan bentuk akronim dari pendek akal. Seringkali, kata pea digunakan sebagai bentuk penghinaan terhadap sesuatu. Penggunaan interjeksi dah dalam data (12) menunjukkan keheranan petutur terhadap penutur cuitan yang dianggap pendek akal karena menghina pacarnya sendiri.

Interjeksi dah pada data (9) dan (12) digunakan secara berbeda. Hal ini menggambarkan bahwa satu interjeksi bisa saja mengisi beberapa fungsi. Perbedaan pemaknaan interjeksi ini disesuaikan dengan kalimat utama dan suasana tuturannya.

\section{e. Interjeksi Ajakan}

Data:

(13) Yuk saling menghargai $y u k$.

(14) Yuk kita cari cewenya yg mana.

Data (13) dan (14), interjeksi yuk sama-sama digunakan untuk mengajak penutur cuitan melakukan sesuatu. Data (13) menunjukkan interjeksi yuk yang digunakan berulang. Hal ini menjelaskan bahwa petutur benar-benar mengajak penutur cuitan agar bisa lebih menghargai pasangannya. 
Adapun data (14) hanya menggunakan interjeksi yuk sebanyak satu kali, yaitu di awal kalimat. Berdasarkan data (13) dan (14), interjeksi yuk bisa digunakan di awal maupun di akhir kalimat. Letak penggunaan interjeksi yuk tidak menunjukkan perubahan fungsi interjeksinya. Baik di awal, tengah, maupun akhir kalimat, interjeksi yuk akan selalu befungsi sebagai interjeksi yang menyatakan ajakan.

\section{Penutup}

\subsection{Simpulan}

Secara keseluruhan, terdapat lima jenis interjeksi yang digunakan dalam komentar terhadap cuitan akun Twitter @asknonym, yaitu (1) interjeksi kekesalan meliputi interjeksi anjir, nyet, dan jingan; (2) interjeksi kekagetan, yaitu interjeksi astagfirullah, wah, dan njir; (3) interjeksi kejijikan, yaitu interjeksi idih, cuih dan dih; (4) interjeksi keheranan, yaitu interjeksi deh, elah, dan dah; serta (5) interjeksi ajakan yaitu interjeksi yuk.

Berdasarkan bentuknya, terdapat dua bentuk interjeksi digunakan dalam komentar terhadap cuitan akun Twitter @asknonym, yaitu interjeksi bentuk dasar dan turunan. Interjeksi bentuk dasar meliputi data (1) anjir, (7) idih, (8) cuih, (9) dih, (10) deh, (11) elah, (12) dah, dan
(13--14) yuk. Adapun interjeksi bentuk turunan merupakan interjeksi yang digunakan setelah melalui pemenggalan, yaitu data (2) nyet, (3) jingan, (4) astagfirullah, dan (6) njir.

\subsection{Saran}

Penelitian mengenai penggunaan bahasa Indonesia dan kategori kata dalam media sosial masih perlu dilakukan. Hal ini disebabkan karena bahasa Indonesia dalam media sosial berbeda dengan bahasa Indonesia yang digunakan dalam situasi formal. Pemahaman yang baik mengenai penggunaan bahasa Indonesia dalam media sosial bisa meminimalkan kesalahpahaman antarpengguna media sosial yang disebabkan oleh berbedanya pandangan mengenai makna cuitan atau unggahan pengguna media sosial tersebut.

\section{Daftar Pustaka}

Akmaluddin, N. (2018). Realitas Penggunaan Bahasa Indonesia Ragam Tulisan Pada Lembaga Pemerintahan. Mabasan, 12 (1), 1-20.

Alwi, H., Dardjowidjojo, S., Lapoliwa, H., \& Moeliono, A. M. (2010). Tata Bahasa Baku Bahasa Indonesia. Jakarta: Pusat Bahasa dan Balai Pustaka.

Azwar, S. R., \& Agustina. (2019). Interjeksi dalam Talkshow "Pagi Pagi Pasti Happy" di Trans TV. 
Bahasa dan Satra, 7(2), 1-7.

Cahyono, A. S. (2016). Pengaruh Media Sosial terhadap Perubahan Sosial Masyarakat di Indonesia. Jurnal IImu Sosial \& IImu Politik Fakultas Ilmu Sosial \& Politik, Universitas Tulungagung, 9 (1), 140-157.

Chaer, A. (2012). Linguistik Umum. Jakarta: Rineka Cipta.

Djajasudarma, F. (2010). Metode Linguistik. Bandung: Refika Aditama.

Fadhilah, I., Armia, \& Iqbal, M. (2019). Analisis Penggunaan Interjeksi dalam Graphic Novel Warkop DKI Reborn Jangkrik Boss! Part 2 Karya Bene Dion Rajagukguk DKK. Jurnal Bahasa dan Sastra, 13 (1), 37-44.

Fitriani, F., \& Endriani, A. (2018). NilaiNilai Kehidupan dalam Novel Dilan, Dia adalah Dilanku Tahun 1990 dan Implementasinya pada Pembelajaran Bahasa Indonesia. Mabasan, 12 (2), 139-150.

Hakim, L., Shubhi, M., \& Hamid, S. A. (2017). Kesalahan Penggunaan Bahasa Indonesia pada Surat Kabar di Kabupaten Sumbawa. Mabasan, 11 (2), 107-118.

Junawaroh, S. (2015). Kajian Deskriptif Struktural Wacana Grafiti pada Truk. HUMANIKA, 21 (1), 49-55.

Kemdikbud. (2016). Kamus Besar Bahasa Indonesia Edisi $V$. [daring]. Diakses dari https://kbbi.kemdikbud.go.id

Kridalaksana, H. (2009). Kamus Linguistik. Jakarta: Gramedia Pustaka Utama.

Kridalaksana, H. (2010). Pembentukan
Kata dalam Bahasa Indonesia. Jakarta: Gramedia Pustaka Utama.

Mansyur, U. (2016). Bahasa Indonesia dalam Belitan Media Sosial: Dari Cabe-Cabean Hingga Tafsir AlMaidah 51. Prosiding Seminar Nasional \& Dialog Kebangsaan Dalam Rangka Bulan Bahasa 2016, 145-155.

Milka. (2012). Analisis Interjeksi Ya! dan Nah! dalam Novel Pemburu Rembulan Karya Arul Chandrana. Jurnal Keguruan dan Ilmu Pendidikan, 1 (1), 49-55.

Nurhadi, Z. F. (2017). Model Komunikasi Sosial Remaja Melalui Media Twitter. Jurnal ASPIKOM, 3 (3), 539-549.

Putrayasa, I. B. (2017). Kajian Morfologi Bentuk Derivasional dan Infleksional. Bandung: Refika Aditama.

Rahmat, W. (2017). Sinisme dalam Kaba Sabai Nan Aluih Suatu Bentuk Pentingnya Bahasa Bahasa Ibu: Kajian Pragmatik. Curricula: Journal of Teaching and Learning, 2 (1), 1928.

Sugiyono. (2017). Metode Penelitian Kualitatif. Bandung: Alfabeta.

Susanti, E. (2016). Glosarium Kosakata Bahasa Indonesia dalam Ragam Media Sosial. DIALEKTIKA, 3 (Oktober), 229-250.

Swandy, E. (2017). Bahasa Gaul Remaja dalam Media Sosial Facebook. Jurnal Bastra, 1 (4), 1-19.

Verlin, S., Darwis, M., \& Hasjim, M. (2018). Abreviasi dalam Media Sosial Instagram. Jurnal Ilmu Budaya, 6 (2), 
277-286.

Widiatmoko, B., \& Waslam, W. (2017).

Interjeksi dalam Bahasa Indonesia:

Analisis Pragmatik. Pujangga, 3 (1), 83-97.

Zaim, M. (2015). Pergeseran Sistem Pembentukan Kata Bahasa Indonesia:

Kajian Akronim, Bleding, dan Kliping. Linguistik Indonesia, 33 (2), 173-192. 
